\title{
Um estranho no ninho: memórias de um ex-presidente da Fiocruz
}

\section{Over the cuckoo's nest: memories of a former president of Fundação Oswaldo Cruz}

\begin{abstract}
A s recentes comemorações em torno do centenário da Fundação Oswaldo Cruz (Fiocruz), realizadas durante o ano de 2000, estimularam-nos a trazer a público a entrevista de Vinícius da Fonseca, presidente desta instituição entre 1975 e 1979. Neste depoimento, concedido à Casa de Oswaldo Cruz (COC) ${ }^{1}$ em 1995, Vinícius da Fonseca reporta-se ao momento de gestação da política de ciência e tecnologia, forjada na década de 1970, notadamente no governo Ernesto Geisel. Decorreu daí a estruturação do moderno sistema científico e tecnológico do país, percebido como um instrumento fundamental do desenvolvimento econômico e social.

Nesse contexto, Vinícius da Fonseca, economista oriundo da Secretaria de Planejamento (Seplan), foi designado pelo então ministro da Saúde, Paulo de Almeida Machado, para reformular as atividades da Fiocruz, visando inseri-la no recém-criado Sistema Nacional de Desenvolvimento Científico e Tecnológico (SNDCT). Nesse sentido, um dos principais objetivos de sua gestão, ao lado da restruturação da área de pesquisa biomédica, foi dotar a instituição de uma infra-estrutura de produção de vacinas capaz de atender às necessidades dos programas de imunização do Ministério da Saúde, bem como contribuir para o projeto a longo prazo de auto-suficiência em imunobiológicos do país.

Mesmo tratando de assuntos polêmicos e controversos sobre um período político conturbado da história do país, Vinícius da Fonseca narra de forma bem-humorada os problemas enfrentados e as principais realizações de sua gestão. Esta entrevista constitui um documento privilegiado para compreender a atual organização institucional da Fiocruz, remontando à restruturação de suas atividades na década de 1970, bem como contribui para o debate sobre os rumos da ciência e tecnologia no país.
\end{abstract}

Wanda Hamilton Socióloga, pesquisadora da Casa de Oswaldo Cruz wandash@coc.fiocruz.br

Nara Azevedo Doutora em sociologia, pesquisadora da Casa de Oswaldo Cruz nazevedo@coc.fiocruz.br

Av. Brasil, 4036/401

21040-361 Rio de Janeiro - RJ Brasil

${ }^{1}$ A íntegra deste depoimento encontra-se no Departamento de Arquivo e Documentação da Casa de Oswaldo Cruz, à Av. Brasil, 4036 sala 602, e integra o projeto Memória de Manguinhos, constituído de um acervo de cerca de quatrocentas horas de entrevistas com cientistas, administradores e técnicos da Fiocruz. 


\section{"A fistória do crescimento de países desenvolvidos passou a ser reexaminada à luz do critério tecnológico. Por que um pais enriquece? Porque ele desenvolve e domina uma tecnologia. Anteriormente à guerra, não se tinha consciência de que havia dois mundos".}

\section{O planejamento de ciência e tecnologia no governo Geisel}

Gostariamos de iniciar esta entrevista comentando o convite que o senhor recebeu do dr. Paulo de Almeida Machado, ministro da Saúde, para assumir a presidência da Fundação Oswaldo Cruz.

Assumi a presidência da Fiocruz em 1975. Fui convidado pelo então ministro da Saúde, dr. Paulo de Almeida Machado, no começo do governo Geisel. Mas creio que vale a pena, antes de dizer exatamente a razão de ser do compromisso, referir ao sistema de governo na época. O sistema, que vinha de alguns anos atrás, estava baseado na Secretaria de Planejamento (Seplan), o órgão de Planejamento e Coordenação Geral que sucedeu ao Ministério do Planejamento.

Dentro desse Ministério do Planejamento, a política nacional de desenvolvimento científico e tecnológico foi desenvolvida a um ponto muito integrado, articulado e muito bem proposto em termos de financiamento. Tenho a impressão de que foi um período, no Brasil, em que se dedicou a maior parcela de recursos à política de desenvolvimento científico e tecnológico.

Havia uma distinção no destino dos recursos para a universidade e para as empresas?

Não havia distinção porque era muito maior o apoio à pesquisa acadêmica, universitária. Não havia no empresariado brasileiro consciência da necessidade de desenvolver tecnologias próprias. $\mathrm{O}$ pouco que se tinha era comprado, antigo e obsoleto. Mas eu diria que, além desse aspecto de fomento à pesquisa científica e tecnológica, houve também uma postura nova que acompanhou o pensamento mundial no sentido de dar uma versão um tanto diferente ao próprio conceito de desenvolvimento econômico das teorias clássicas, baseado, fundamentalmente, no desenvolvimento do capital. Esse conceito teórico de desenvolvimento econômico dominou a política de concentração de renda que vinha sendo implementada desde o governo de Getúlio Vargas. Creio que depois da década de 1950, quando o mundo começou a perceber e a evidenciar a dicotomia entre o mundo pobre e o mundo rico, entre o Sul e o Norte, surgiu uma outra visão do que estava realmente na base do desenvolvimento econômico. A história do crescimento de países desenvolvidos passou a ser reexaminada à luz do critério tecnológico. Por que um país enriquece? Porque ele desenvolve e domina uma tecnologia. Anteriormente à guerra, não se tinha consciência de que havia dois mundos. No pós-guerra, com a primeira reunião dos países na Organização das Nações Unidas (ONU), é que se começou a ver: de um lado, os Estados Unidos, do outro, a Índia; de um lado, a Inglaterra, do outro, a Libéria. A ONU foi um ponto de encontro e de discussão. De repente, o mundo deparou-se com órgãos econômicos como, por exemplo, a Comissão Econômica para a América Latina (Cepal), que começou a encarar o problema do 
"Você não pode estar comprando tecnologia. Tecnologia se aprende, se faz, não se importa". desenvolvimento econômico nas áreas pobres da América Latina. Estou dizendo coisas que são sabidas, mas quero rememorar por que este conceito passou a ser cada vez mais importante e a tecnologia encarada como um fator decisivo.

\section{Como esse pensamento se manifestou no Brasil?}

Dentro do próprio governo brasileiro, havia correntes ortodoxas, monetaristas, como a do Eugênio Gudin, que tinha uma visão antiga. Para ele, o problema eram os instrumentos monetários e fiscais. A tecnologia era um elemento secundário que poderia ser comprado. Os pensadores de acordo com a tendência da tecnologia apareceram nos governos militares. Esta visão passou a vigorar a partir de Castelo Branco, mas, sobretudo, Costa e Silva, e fundamentalmente, Geisel. E eu diria que uma das pessoas mais importantes foi João Paulo dos Reis Veloso. Num fórum de debates na Câmara dos Deputados, ele disse: "A melhor forma de manter um país permanentemente subdesenvolvido é entregar-lhe sempre uma tecnologia pronta e acabada, que ele tenha apenas de usar." Creio que isso caracteriza bem uma visão nova. Você não pode estar comprando tecnologia. Tecnologia se aprende, se faz, não se importa.

Como o dr. Reis Veloso tinha abertura para essa nova visão do desenvolvimento?

Essa opinião era partilhada até por adversários ideológicos e políticos do Reis Veloso, como Celso Furtado. Todos estávamos de acordo porque estudávamos o desenvolvimento econômico e o fator decisivo não era mais somente o capital, como eu falei, mas a tecnologia. Quem domina a tecnologia, domina o mundo, domina a economia. Eu acho que era uma questão de sensibilidade política e, sobretudo, social. As pessoas voltadas para o problema do desenvolvimento brasileiro - como Reis Veloso, eu, e vários outros - estavam integradas num governo que tinha como objetivo central desenvolver o país. Era um problema e um desafio para todos nós. Realmente era uma paixão. Estávamos afinados com o pensamento mundial e esse pensamento levava para o problema da tecnologia.

\section{Esse era o pensamento da Secretaria de Planejamento?}

A Secretaria de Planejamento era o ponto focal disso. Ela liderava de tal maneira que o sistema de desenvolvimento científico e tecnológico terminou passando para o âmbito do Ministério do Planejamento. O ministério formulou a visão global do problema sob a ótica do desenvolvimento auto-sustentável, uma expressão muito usada na época, que representava dar força ao processo nacional de desenvolvimento de ciência e tecnologia. Eu diria que foi, sem dúvida, uma política nacionalista, se quisermos usar esse termo. Tínhamos consciência de que a ciência é universal, mas existem uma ciência e uma tecnologia 
"No governo Costa e Silva, os militares disseram que não iam entregar o poder. Essa foi a outra face, que continuou com Médici. Mas havia, evidentemente, uma opinião dentro e fora do governo que não estava de acordo com esse lado exclusivamente militar do Brasil como potência nacional: "ame-o ou deixe-o"." nacionais, que são preservadas em qualquer país, e não podem ficar dependentes de uma soberania externa ou de uma empresa privada do exterior. É preciso fazer esse esforço para obter autonomia tecnológica e científica na visão de que foram os avanços tecnológicos que permitiram aos países hoje ricos se desenvolverem. É a demanda tecnológica que provoca o crescimento científico. Ou seja, não se faz ciência bizantina, não existe sexo dos anjos. Um cientista puro não é mais nem menos do que fruto de uma demanda global da sociedade. Ele pode até não saber que faz parte de um contexto, mas ele faz. Ele não pode de repente imaginar que vai estudar o sexo dos habitantes de Marte. Por que o cientista não estuda o sexo dos habitantes de Marte? Porque não corresponde a nenhuma necessidade social. $O$ ser humano é social por excelência.

Como foi se firmando essa politica de ciência e tecnologia nos governos militares?

Os militares fizeram um governo para consolidar o movimento militar, mas com vistas a repassar o poder aos civis após o governo Castelo Branco. No governo Costa e Silva, os militares disseram que não iam entregar o poder. Essa foi a outra face, que continuou com Médici. Mas havia, evidentemente, uma opinião dentro e fora do governo que não estava de acordo com esse lado exclusivamente militar do Brasil como potência nacional: "ame-o ou deixe-o". Havia uma linha no governo que pensava diferente. Achava que tudo isso era muito bonito para parada militar e que era preciso consolidar uma estrutura de produção interna, não baseada apenas no aumento da capitalização. Era necessário ter domínio tecnológico. Acredito que o Brasil nunca teve até então uma política de ciência e tecnologia tão explícita, tão bem montada. $\mathrm{Na}$ verdade, foi no governo Geisel que se montou uma estrutura de ciência e tecnologia com um programa e com a participação dos órgãos de ciência e tecnologia, das universidades, dos congressistas, enfim, dos formadores de opinião e do governo. Era uma decisão política.

Por que Geisel deu esse apoio?

Creio que Geisel tinha uma noção de sentimento público muito forte. Ele era um homem que tinha uma missão militar a cumprir. Tinha recebido uma missão social, mas ele via isso com olhos militares. Ele tinha uma formação muito ampla, e um passado de experiência na Petrobras. Ele fez reuniões no Conselho Nacional de Desenvolvimento Científico e Tecnológico (CNPq), coisa inédita no Brasil. Ele tinha essa predisposição, embora eu acredite que ficou influenciado pelo convívio próximo com o Reis Veloso, com esse pensamento.

Quem articulou a política de ciência e tecnologia?

Basicamente o Ministério do Planejamento, através dos Planos Nacionais de Desenvolvimento e dos Planos Básicos de Desenvolvimento 
"Comecei a atuar na saúde como ligação com o Planejamento, com o dr. Paulo de Almeida Machado. Até então, o

Ministério da Saúde era inexpressivo, quase não existia".
Científico e Tecnológico. O CNPq, órgão vinculado diretamente ao presidente da República, tinha uma atuação relativamente pequena. Passou a ser vinculado ao Ministério do Planejamento e a ter uma expressão muito maior do que no passado, por uma razão: teve muito mais dinheiro.

O governo destinou recursos especificos para isso?

No orçamento da União houve um item específico para ciência e tecnologia. Até o governo Geisel, era o Ministério da Fazenda que controlava o orçamento e a execução financeira. Ficávamos do lado de fora e, na hora agá, quem resolvia eram os outros. Por isso houve uma reformulação: o Banco Central, o CNPq, a estrutura de informação, de controle orçamentário, financeiro e de execução passaram para o Ministério do Planejamento. Foi Geisel quem implantou isso.

O Ministério do Planejamento tinha esse poder?

O Ministério do Planejamento, de certa forma, mandava bastante no país porque quem manda no orçamento manda à beça. E o ministro do Planejamento conseguiu uma situação privilegiada, ele ficava junto do presidente.

De onde vinha a força política do Reis Veloso?

No governo militar, força política era força intelectual. Houve, já se disse isso tantas vezes mas é bom a gente repetir, a famosa tecnocracia misturada com o militar. Os militares buscavam nos tecnocratas a capacidade intelectual que lhes desse o embasamento de que precisavam. E, realmente, criaram uma estrutura de trabalho muito boa que permitiu a nós civis desenvolver nossas idéias: tínhamos liberdade de falar e de pensar.

Tinha o quadro técnico, o lado da economia, e a repressão política. Pelo que o senhor está dizendo, vocês não se envolviam com esse lado.

Não sabíamos, não tínhamos informação. Aliás, o povo não tinha noção de modo geral. Não nos envolvíamos. Na verdade, o problema do Araguaia só veio a ser descoberto, em termos nacionais, pela revista Veja muitos anos depois. Foi segredo total.

Sua aproximação com a saúde se deu na gestão do ministro Paulo de Almeida Machado?

Eu fui para o Instituto de Pesquisa Econômica Aplicada (Ipea) a convite do Reis Veloso em 1965, fui um dos fundadores. No Ipea havia vários setores, cada um deles coordenado por uma pessoa. Eu era coordenador da área social, ligada a habitação, saneamento, saúde e previdência social. Comecei a atuar na saúde como ligação com o Planejamento, com o dr. Paulo de Almeida Machado. Até então, o Ministério da Saúde era inexpressivo, quase não existia. Tinha um 
"O Brasil, como

país ainda pobre, que tem uma taxa de mortalidade elevada, sobretudo com doenças parasitárias e infecciosas, não pode estar dando preferência à medicina curativa que trata de coração e outras coisas assim". orçamento mínimo, algo como 4\% do orçamento da União. Na verdade, quem mandava na saúde era o Inamps, o antigo INPS. Realmente, a estrutura e as grandes lideranças de saúde no Brasil eram todas ligadas ao Inamps.

O senhor podia nos explicar qual o teor dessa divisão?

Naquela época, na área de saúde havia uma separação muito grande entre os defensores da saúde preventiva e da saúde individual. A Escola Nacional de Saúde foi uma das pioneiras dessa linha de saúde preventiva. Dentro do próprio Inamps, havia um grupo que lutava por isso. O Carlos Gentile, um dos grandes batalhadores dessa linha, mostrou estatisticamente algo muito sério: certas cidades brasileiras tinham a maior taxa de cesarianas do mundo. Paulo de Almeida Machado, que era paulista, se ligou a um grupo de São Paulo vinculado a essa nova visão de prevenção da saúde pública, que coincidia com a minha idéia e a do Reis Veloso.

Então o ministro Paulo de Almeida Machado compartilhava das idéias do Planejamento?

Sem dúvida. Lutávamos para que houvesse uma unificação do sistema de saúde no país e se acabasse com essa história de Inamps para um lado e Ministério da Saúde para outro. Acredito que desviar dinheiro público para convênios com a clínica privada não tem sentido. Tenho um documento do Ministério da Saúde, do ministro, que retrata muito bem essa visão. Paulo de Almeida Machado foi, no meu entender, um homem extraordinário, um dos maiores ministros da Saúde e estadistas que nós tivemos. Ele deu ao Ministério da Saúde um outro sentido, uma dimensão maior. Foi ele quem deu a grande guinada da mudança da saúde pública. Transformou um Ministério da Saúde pequeno em um ministério que cuida de saúde preventiva.

Como se pensava a Fiocruz nesse sistema de saúde?

A política era geral. A saúde estava dentro de uma idéia global. $\mathrm{O}$ Brasil, como país ainda pobre, que tem uma taxa de mortalidade elevada, sobretudo com doenças parasitárias e infecciosas, não pode estar dando preferência à medicina curativa que trata de coração e outras coisas assim. Hoje o quadro mudou bastante, mas há vinte anos atrás havia problemas muito sérios de saúde pública. A saúde pública devia se desenvolver. Então, a pesquisa deveria se voltar, de preferência, para a saúde pública.

Por que o dr. Paulo o convidou para a presidência da Fiocruz?

O Paulo de Almeida Machado passou um período grande tomando pé no ministério. Foi quando ele conheceu bem Manguinhos. Ele me disse que Manguinhos era um enorme desafio. Ele estava realmente precisando de alguém. Um dia ele me disse: "Eu acho que não deve ser 
um homem de lá. Não deve ser um pesquisador nem um médico. Eu acho que tem que ser uma pessoa alheia ao meio, e até alheia ao assunto." Então percebi a intenção dele: um homem ligado ao governo, um homem de formação econômica. Era o meu perfil. Eu estaria indicado, segundo ele, porque estava dentro do espírito do Ministério da Saúde. Fiz a recuperação de Manguinhos como qualquer um do staff do Reis Veloso poderia fazer, porque tínhamos mentalidade de planejamento. O planejador tem uma idéia política, de conjunto, integrada a um projeto econômico-social. Mas, na verdade, se não fosse o dr. Paulo, não teria acontecido isso com Manguinhos, porque o Reis Veloso tinha outras prioridades.

A prioridade do Reis Veloso não era a saúde?

Não, definitivamente não era a saúde. Ele tinha que dar prioridade aos projetos de desenvolvimento tecnológico de alto nível, às áreas de ponta, como metalurgia, mecânica avançada, energia nuclear, que era a sua menina dos olhos. Enfim, todos esses setores onde o Brasil não tinha quase nada.

\section{A chegada em Manguinhos}

Quando o senhor assumiu a Fiocruz?

Fui convidado em maio, mas só pude assumir no dia 22 de julho de 1975. Esse período de quase dois meses foi, em primeiro lugar, devido a uma certa surpresa para mim, pois eu teria que entender bem o que ia fazer. Em segundo lugar, eu tive que conversar com algumas pessoas, sobretudo com o ministro Reis Veloso, com quem eu tinha compromissos profissionais e afetivos. Veloso não estava muito favorável à minha saída do planejamento. Até que fiquei entusiasmado com o desafio.

Mas ele the deu uma orientação do que o ministério precisava de Manguinhos?

Esse tipo de conversa não aconteceu, porque havia um entendimento tácito. No governo Geisel, esse novo conceito de ciência e tecnologia começou a surgir de forma muito forte, como acabei de dizer. Houve três Planos Nacionais de Desenvolvimento e dois Planos Básicos de Desenvolvimento Científico e Tecnológico. Pode-se perceber a importância que se deu ao setor de desenvolvimento da ciência, que chamavam na época de pesquisa e desenvolvimento. A chamada recuperação de Manguinhos que me coube foi uma decisão política do governo no contexto da política de desenvolvimento científico e tecnológico do país. Portanto, não dependeu de coisas supérfluas ou de acontecimentos como a crise da meningite. 


\section{"Manguinfos estava morto. Quando eu assumi, o dr. Paulo de Almeida Machado, ministro da Saúde, disse de viva voz para a platéia: —Esse aqui é o fomem que vai ressuscitar esse cadáver insepulto".}

Mas havia uma proposta concreta, uma área que o dr. Paulo quisesse priorizar?

Ele via Manguinhos como uma continuação daquilo que foi no passado. Ele tinha a proposta de transformar, quer dizer, de recuperar. E me apoiou totalmente, sem dúvida nenhuma. Era realmente um enorme desafio. E eu tive que me preparar para isso me informando do que era Manguinhos e por que tinha chegado àquilo. A credibilidade da instituição estava a zero. Isso eu senti porque amigos meus do próprio governo, quando me ouviram dizer que ia para Manguinhos, ficaram espantados.

E qual era a situação de Manguinhos?

Manguinhos estava morto. Quando eu assumi, o dr. Paulo de Almeida Machado, ministro da Saúde, disse de viva voz para a platéia: "Esse aqui é o homem que vai ressuscitar esse cadáver insepulto." Palavras dele. Então vocês vêem o que era Manguinhos. Agora, por quê? Porque houve a cassação? Não. Eu vim a saber do famoso "massacre de Manguinhos" já como presidente da fundação. Parece incrível isso! Cassar os direitos políticos de um pesquisador como o Herman Lent, o Haity Moussatché e outros, meu Deus, tem sentido isso? Realmente, não fazia o menor sentido. A minha interpretação é de que havia problemas profundamente pessoais, ódios acumulados durante anos.

Esses conflitos se acirraram quando Rocha Lagoa assumiu a direção do Instituto Oswaldo Cruz em 1964.

Eu não sabia nada da fundação. O dr. Genard Nóbrega e o dr. Wladimir Lobato Paraense, que conhecem a história de Manguinhos, me disseram que quando houve a revolução de 1964 o Rocha Lagoa dominou o Instituto Oswaldo Cruz. Ainda não havia fundação, foi ele quem depois a criou. Ele se apossou de Manguinhos com o grupo dele, de extrema direita, sei lá se tinha ideologia nisso. Em 1970, ele foi chamado pelo Costa e Silva para ser ministro da Saúde e se aproveitou do ministério para fazer o chamado "massacre". Foi o único local no Brasil em que cientistas e professores tiveram seus direitos políticos cassados. Realmente, o "massacre de Manguinhos" foi uma coisa extremamente paroquial. Eu não estou querendo dizer que os cientistas que foram cassados fossem inexpressivos. Eu quero dizer que não houve repercussão porque Manguinhos já tinha perdido a sua função social. Antes das cassações, Manguinhos já estava morto. Pode uma entidade morrer em cinco anos porque foram cassadas dez pessoas? Não, não pode. A instituição tinha morrido há muito tempo. Havia grupos politicamente adversários: um de esquerda e um de direita, e esses grupos se digladiando o tempo todo, conflitando de uma forma tremenda, deixaram de produzir cientificamente. Manguinhos não tinha mais legitimidade. 
"A febre amarela era algo tão horrivel que o Brasil perdeu dinheiro ... $\mathrm{O}$ que Oswaldo Cruz fez? Ele se mostrou um demandador de tecnologia, criou toda uma estrutura em torno disso não só para fazer vacina, mas para produzir conhecimento".
Por que Manguinhos perdeu a legitimidade?

O que houve no caso específico da fundação e de várias instituições brasileiras foi uma perda de utilidade social, que decorreu da falta de articulação desse sistema científico com o meio social do país. Quando Oswaldo Cruz dizia que queria dinheiro para fazer vacina de febre amarela, ele correspondeu a um momento histórico. A febre amarela era algo tão horrivel que o Brasil perdeu dinheiro, não podia exportar porque os navios não vinham mais aqui. Era um problema nacional da maior importância. O que Oswaldo Cruz fez? Antes de mais nada, ele se mostrou um demandador de tecnologia, criou toda uma estrutura em torno disso não só para fazer vacina, mas para produzir conhecimento e ensinar através do Curso de Aplicação. Aos poucos, o país foi tendo outras necessidades na área de saúde. Na época de Oswaldo Cruz, nossa população era totalmente rural, daí o problema da doença de Chagas, de esquistossomose. O Brasil tinha $20 \%$ de população urbana, se tanto. Aos poucos, aos trancos e barrancos, como diz o Darcy Ribeiro, o país foi crescendo, foi mudando. Já em 1950, quando comecei a trabalhar no recenseamento do Instituto Brasileiro de Geografia e Estatística (IBGE), a população urbana brasileira chegava a 40\%, 45\%. Chegamos, na década de 1960, com uma mudança bastante forte, acentuada no governo Juscelino, com todo um desenvolvimento de mentalidade, com a criação de órgãos como o Banco Nacional do Desenvolvimento Econômico e Social (BNDES), com toda uma estrutura de crescimento, de industrialização. $\mathrm{E}$ isso, evidentemente, se retratou na área da saúde. As doenças passaram a ser outras. O campo de pesquisa e tecnologia no setor biomédico transformou-se também, passando a dar maior importância, por exemplo, à virologia e à imunologia em vez da bacteriologia. Manguinhos não tinha nada disso. Essa é a realidade. Quer dizer, todas as novas necessidades foram sendo deixadas para trás, porque Manguinhos não tinha uma estrutura capaz de enfrentar isso nem podia acompanhar esse processo. Ficou na bacteriologia clássica, ficou na parasitologia. Enfim, a fundação ficou naquilo que era há trinta, quarenta anos atrás, vivendo de seus louros, mas os louros se transformaram em espinhos. Ninguém sabia o que era Manguinhos. A instituição perdeu a sua autoridade de pesquisa social, perdeu o seu sentido. Não sabia reivindicar nada mais, porque não se pode reivindicar uma coisa que a sociedade não sabe o que é. Manguinhos das décadas de 1960 e 1970 em diante não tinha mais sentido histórico. Tinha perdido essa capacidade.

Qual foi a sua atitude diante desse quadro de perda de legitimidade da instituição?

Eu quis legitimar Manguinhos e o ministro também queria. Eu quis explicitar para o mundo científico, administrativo e político que a recuperação era um objetivo de governo, do presidente da República. Por isso fiz questão de que na minha posse houvesse uma certa 
pompa. Presidente da fundação era segundo escalão, mas eu tive na minha posse quatro ministros, o presidente do CNPq, da Financiadora de Estudos e Projetos (Finep), do BNDES. Evidentemente o ministro da Saúde sabia que eu tinha que fazer valer essas relações para poder me impor, porque a instituição tinha caído a um ponto tal que, sem isso, não tinha como. Na posse em Brasília houve essa concorrência, e a posse em Manguinhos foi um comício. Eu quis dar essa demonstração pública de que estava imbuído de uma função pública. A recuperação de Manguinhos precisava ser prioritária. Por isso aproveitei, sem nenhuma dúvida, a $5^{\text {a }}$ Conferência Nacional de Saúde, que se realizou poucos dias depois da minha posse. Nessa conferência, o ministro da Saúde colocou na boca do presidente da República as palavras que eu traduzo aqui: "A recuperação da Fundação Oswaldo Cruz, instituição de prestígio internacional, representa precondição e conseqüência de um programa de articulação entre a política de desenvolvimento científico e tecnológico e a política nacional de saúde, com vistas à indispensável modernização do aparelho produtor de serviço e de saúde.” Essa manifestação, que evidentemente foi reproduzida nos jornais e no meio governamental, era muito importante. Com isso, estavam me dando uma missão de governo.

Quais foram as primeiras medidas que o senhor tomou ao assumir o cargo?

Resolvi ir a Manguinhos antes de assumir a presidência. Fiz uma visita com o dr. Genard, à época diretor do Instituto Oswaldo Cruz. Ele foi uma das primeiras pessoas que eu procurei pelo fato de ser tio de um amigo de infância. A família Nóbrega é paraibana, como eu. $\mathrm{O}$ dr. Genard era um homem extremamente tímido, muito discreto, de personalidade tranqüila, e não soube me transmitir muita coisa, embora depois ele tenha me mostrado coisas lá dentro. Foi ele quem me levou para ver o local onde os bandidos distribuíam maconha.

Havia um ponto de venda de drogas em Manguinhos?

Claro, tinha ponto de tudo em Manguinhos. Eu vi o horror que era aquilo. Realmente tinha caído num descrédito tal que fazia medo. É indescritivel como pode ter chegado a um ponto daquele. Tinha quartos de motel com luz vermelha e tudo, um deles dentro da garagem do ministro! E quem descobriu esse quarto foi o próprio ministro da Saúde! Ele chegou uma noite lá e me disse que foi um rebuliço, um correcorre. O motel estava sendo utilizado. Havia outras coisas assim. O zelador tinha uma extensão do telefone da diretoria de Manguinhos. As padarias de Bonsucesso compravam lenha de Manguinhos. Foi o ministro da Saúde também quem me falou.

Roubavam lenha de Manguinhos?

O ministro tinha um gabinete no prédio do Ministério da Saúde, onde vocês estão hoje. Ele era muito cioso de Manguinhos. Ele viu e 
"Nõo entendo

como uma

instituição pôde

cair àquele nível.

Esse também era

um dos motivos

pelos quais a

pesquisa e as

atividades-fins

não podiam se

realizar. Morar e

trabalhar em

Manguinhos

passou a ser um

horror $e$

desprezivel

porque ganhava-

se muito pouco.

Todos os

pesquisadores

trabalhavam

quatro horas por

dia”. me telefonou na hora: "Vinícius, bota o seu pessoal para interceptar um caminhão." "O que há ministro?" "Estão levando lenha." Eu interceptei e peguei em flagrante. Era um freguês de Manguinhos. Havia uma aléia de pau-mulato que era linda. Eles cortaram o pau-mulato para fazer lenha. Era o cúmulo! Manguinhos não tinha cerca. Era inteiramente aberto ao público na avenida Brasil - uma área com 750 mil metros quadrados aberta e com locais extremamente propícios para se esconder. O ambiente físico em Manguinhos era o pior possivel, o mero transitar pelo campus - depois inventei esse nome que pegou - tornara-se arriscado. Trinta e quatro roubos e assaltos foram registrados entre janeiro e setembro de 1975, eram mais de três roubos por mês!

O senhor está pintando um quadro de decadência terrivel!

Realmente, era impressionante. Foi preciso criar a Swat (atualmente é o setor responsável pelo transporte no campus, mas, inicialmente, cuidava da limpeza) para percorrer o campus e descobrir os horrores. Minha mulher deu esse nome porque havia um seriado na TV, que mostrava jovens com coragem para fazer a limpeza grossa, braba. Andavam de bota de cano longo e, às vezes, usavam máscara. Por exemplo, dentro de Manguinhos havia, a céu aberto, um esgoto sanitário in natura que vinha da favela e atravessava o campus. Nós tiramos durante os primeiros meses cinqüenta toneladas de lixo e de sucata de dentro do campus. A famosa Casa Amarela tinha de três a quatro metros de material velho de vacina enterrado. Quando eu estava morando em Manguinhos, meu filho um dia foi lá e se cortou. Foi horrivel! O menino parecia um monstro. Quer dizer, ele ficou vacinado pelo resto da vida, me disse dr. Potsch: "Esse daí não vai mais morrer de doença infecciosa." Não entendo como uma instituição pôde cair àquele nível. Esse também era um dos motivos pelos quais a pesquisa e as atividades-fins não podiam se realizar. Morar e trabalhar em Manguinhos passou a ser um horror e desprezivel do ponto de vista social, porque ganhava-se muito pouco. Todos os pesquisadores trabalhavam quatro horas por dia. Não havia tempo integral, a não ser os que tinham recursos do $\mathrm{CNPq}$, que não eram muitos. $\mathrm{O} C N P q$ também desprezava a instituição. A instituição chegara a esse nível de decadência, de prostração.

\section{A recuperação de Manguinhos}

Como o senhor começou a pôr ordem na casa?

Apesar da minha disposição, foi preciso muito tempo para poder tomar pé. $\mathrm{O}$ ministro Rocha Lagoa usou um artifício que estava em moda na época: as fundações. $\mathrm{O}$ próprio Ipea tinha aberto o caminho, era uma fundação. Virou uma panacéia: tudo ia dar certo se se transformasse numa fundação. O que fez Rocha Lagoa? Juntou várias 
instituições que existiam no ministério: o Instituto Oswaldo Cruz, o Instituto Fernandes Figueira, que era um hospital materno-infantil, o Instituto de Leprologia, os chamados núcleos do INERu em Salvador, Belo Horizonte e Recife, a Escola Nacional de Saúde Pública, que se chamava Instituto Castelo Branco, o Instituto de Produção de Medicamentos (Ipromed) e o Instituto Evandro Chagas de Belém do Pará. A idéia era fazer uma fundação provedora de recursos financeiros, e cada instituto tinha total autonomia. Cada um tinha a sua administração, seu quadro de funcionários com as suas leis, seus planos de carreira, seu equipamento. Cada diretor de unidade fazia a sua política e a sua administração, não porque quisesse, mas porque a instituição foi feita para isso. $\mathrm{O}$ projeto da fundação foi esse: cada um com a sua autonomia. Era algo totalmente sem sentido. Durante uns seis meses, eu tive que saber o que era cada um desses órgãos.

Não havia uma administração central?

Não. Eu queria deixar bem claro isso: o ministro Rocha Lagoa pensou que estava descobrindo a pólvora, que ia salvar a pátria criando uma fundação, mas estava errado. Essa não era a solução. Agregou tudo, mas nada funcionava. Foi pior, porque cada um ficou no seu lado. Os recursos não eram suficientes e o arbítrio continuou talvez muito mais forte. Quer dizer, cada um puxava para o seu lado e as dissensões aumentaram. A fundação perdeu seu sentido social, seu sentido nacional, perdeu tudo. E numa situação dessas, o órgão perde também dinheiro. Ninguém vai dar verba para um órgão que não sabe nem pedir dinheiro. $\mathrm{O}$ serviço público, como qualquer empresa privada, vive disso.

Nesse contexto, quais eram as funções do presidente?

A figura do presidente era totalmente sem sentido. Foi colocada lá porque era uma fundação que, em princípio, tinha que ter um presidente. Nos primeiros meses, eu perambulava. Era surrealista a coisa! O presidente andando e se apresentando. Porque veja só: a minha posse foi muito concorrida, mas por pessoas de fora da fundação e por pessoas de dentro da fundação que estavam mais ou menos a par das coisas. Mas a grande maioria não tomava nem conhecimento. $\mathrm{O}$ presidente não tinha gabinete. Descobri duas ou três salas no Pavilhão Rockefeller. Fiquei lá. Tomei emprestado um ramal de telefone, porque também não tinha telefone, e comecei a estudar o que era Manguinhos realmente.

Quer dizer que seu primeiro passo foi colocar a autoridade do presidente?

Exatamente. Eu tinha que fazer isso ou não havia presidência. Daí a centralização que eu fui praticamente obrigado a fazer. Quer dizer, teria que centralizar e ter autoridade. Realmente, foram precisos vários meses. Assumi em julho e só em abril de 1976, quer dizer, dez meses 
"Foi preciso fazer todo um trabalho de infra-estrutura, esgoto, saneamento, reconstituiçãa de linha elétrica. Consegui formular toda a restruturação da entidade, com base no Plano de Recuperação, que foi aprovado pelo ministro em abril de 1976". depois tive condições de apresentar ao ministro um projeto do novo estatuto com a reorientação da instituição.

A transformação que o senhor pretendia exigia altos investimentos. Como conseguiu os recursos?

Tem-se prestígio e poder quando se tem dinheiro. Essa é a realidade. Se você não tiver os recursos, não adianta ter um órgão e desenvolvêlo simplesmente para fazer reuniões científicas. Quando assumi Manguinhos, o orçamento era de 150 milhões de cruzeiros. Havia necessidade absoluta de algum recurso extra. Como eu disse, eu conhecia os meandros do orçamento e consegui recursos do que se chamava Serviços em Programação Especial. Era uma escapatória para se conseguir recurso extra dentro do Ministério do Planejamento, que manobrava o orçamento. Mas evidentemente que para ter dinheiro era preciso apresentar um programa. Por isso, fui obrigado a fazer um programa. Para dar saída à recuperação do órgão, consegui imediatamente 55 milhões de cruzeiros, um terço da média orçamentária.

Esses recursos foram posteriormente incorporados ao orçamento da Fiocruz?

Esses recursos deram margem para se fazer uma nova projeção orçamentária, na qual constavam todas as necessidades para a recuperação, que contemplavam, de um lado, a área física, e de outro, a área humana. Na área humana, o Plano de Cargos e Salários, para aumentar e melhorar o pagamento do pessoal. Na parte física, o abastecimento de bens, a renovação de materiais e equipamentos. $\mathrm{O}$ instituto tinha sessenta mil metros de área construída. Desses, provavelmente quarenta mil metros estavam absolutamente improdutivos e podres. A expressão é essa. Foi preciso fazer todo um trabalho de infra-estrutura, esgoto, saneamento, reconstituição de linha elétrica. Consegui formular toda a restruturação da entidade, com base no Plano de Recuperação, que foi aprovado pelo ministro em abril de 1976. O ministro levou ao presidente um decreto, tornando-o um plano de governo.

Mas voltando ao estatuto, quais as diretrizes estabelecidas?

Nesse novo estatuto propusemos a restruturação organizacional com as unidades que existem até hoje: o IOC, a Escola Nacional de Saúde Pública, Far-Manguinhos e Bio-Manguinhos, o Instituto Fernandes Figueira e os centros regionais. Foram criadas também duas vicepresidências. Eu chamei o dr. Lobato Paraense para a vice-presidência de Pesquisa e Guilardo Martins para a vice-presidência de Recursos Humanos. Na parte administrativa, criamos também a Superintendência de Administração, com vários setores: financeiro, contabilidade, contadoria e controladoria, uma unidade de controle interno que examinava todas as contas para o Tribunal de Contas. Então tivemos 
"Em órgãos

como a fundação

havia uma

Assessoria de

Segurança e

Informações

(ASI), para a qual

foi indicado o

coronel

Gonçalves e mais

três pessoas. Eu o

conheci quando

ele veio se

apresentar: -

Presidente, eu

sou o fomem do

SNI aqui dentro". autonomia, passamos a ter um caixa. A presidência tinha uma assessoria técnica muito reduzida. Tinha ainda o Escritório de Administração de Obras, que depois ficou ligado à Prefeitura do Campus, que nós criamos também. Eu dei esse nome até pomposo, mas acho que ficou bonito. Reconheço que tinha um pouco de vaidade em criar nomes: o campus de Manguinhos. Aquilo deu à instituição um certo nível de universidade, de instituição de pesquisa, de ensino, e uma certa unidade, o que era mais importante. A Comissão Geral de Licitações foi instituída porque, de acordo com a lei, para comprar e vender coisas tem que licitar.

\section{E a Assessoria de Segurança e Informações?}

Tinha que criar de qualquer maneira, era uma imposição do sistema. Essas pessoas eram designadas pelo ministro-chefe do Serviço Nacional de Informações (SNI), que era um sistema nacional. A KGB, a CIA, todo sistema de informação é assim. Todos os ministérios tinham o seu Departamento de Segurança e Informações (DSI), que era ligado diretamente ao chefe do SNI. O chefe do DSI do Ministério da Saúde era um brigadeiro. Em órgãos como a fundação havia uma Assessoria de Segurança e Informações (ASI), para a qual foi indicado o coronel Gonçalves e mais três pessoas. Eu o conheci quando ele veio se apresentar: "Presidente, eu sou o homem do SNI aqui dentro."

Na prática, como funcionava essa ASI?

Toda vez que a gente tinha que nomear uma pessoa e, às vezes, até em casos como, por exemplo, de viagens para o exterior, tinha que passar pela ASI, que encaminhava ao DSI, que por sua vez enviava ao Serviço Nacional de Informações. Quer dizer, os órgãos ministeriais não tinham uma estrutura. O SNI tinha os seus informantes e os meios para se informar. $O$ chefe da ASI na fundação não pesquisava, mandava os nomes para o serviço de informação central. Cabia à ASI me mandar a ficha quando a pessoa não era aceita. Quando era aceita, ela nem dizia nada, eu nem sabia. Quando chegava uma ficha dizendo "não satisfaz", eles diziam: "O senhor faz o que achar melhor."

\section{Era um poder maior que o do ministro?}

Era um poder enorme, tremendo. A área de segurança nacional foi criada pelos governos militares como uma estrutura autônoma e quase soberana. $\mathrm{O}$ ministro e o presidente da fundação não tinham nada a ver com isso. O Serviço Nacional de Informações era um órgão que tinha uma autoridade, digamos, quase equivalente à do presidente da República. Basta ver que Médici e Figueiredo foram do Serviço Nacional de Informações. Era a coisa mais forte dentro do governo. Eles fizeram uma estrutura de acordo com a qual todas as instituições de governo, paraestatais ou ligadas ao governo por algum motivo eram obrigadas a ter uma assessoria. Mas esse poder tinha um limite. Eu passei por esse 
“.. o SNI não era

- bicho-papão

que se diz. Tanto

assim que foi

possível nomear

um homem como

- Carlos Morel,

duas vezes

vetado, e o

Antônio Sérgio

Arouca, primeiro

colocado em um

concurso público

realizado pela

Escola Nacional

de Saúde Pública

(ENSP)..." limite, nomeei pessoas que não eram aceitas. Eu assumi isso e o dr. Paulo de Almeida Machado também.

\section{Qual era a sua relação com a ASI?}

Eu tinha boas relações com ela, mas preferia não entrar em detalhes porque sabia que ia ter problemas. De vez em quando, o coronel tinha atrito comigo. Ele ficava chateado, porque tinha que se explicar perante o chefão dele. Como é que eu nomeei o Morel? Ele me disse uma vez: "Você vai terminar ficando malvisto." Aí eu disse: "Pelo amor de Deus! Eu já fui malvisto no Ministério do Planejamento. $O$ seu serviço me vetou, não me deixou ir para os Estados Unidos, porque eu fui diretor de um jornal comunista quando tinha vinte e poucos anos."

\section{Ele respeitava a sua autoridade?}

Ele respeitava, sem dúvida. Tanto assim que esses casos passaram pela mão dele. Ele sempre me tratou de presidente, como todos lá. Eu impus isso até à minha secretária.

$\mathrm{Na}$ verdade, o senhor era o chefe dele.

Não, não era. Ele assumia até certo ponto, pois tinha a consciência militar de que eu era o chefe.

Ele the criou algum constrangimento?

Não, se eu nomeei, como é que eu ia ficar constrangido? O SNI respeitava ou tinha consideração com a autoridade que se fazia respeitar. $\mathrm{O}$ que o SNI podia fazer o era me fichar como subversivo. O que significava isso? Colocar-me para fora do governo? Mas como eu, várias outras pessoas fizeram a mesma coisa. Dentro da estrutura da Finep, do IBGE, do Planejamento houve casos de pessoas que eram contraindicadas. Eu nomeei vinte pessoas contrariando a opinião do SNI, que tinha uma importância fundamental no governo. Como se explica que um homem de segundo escalão como eu, numa fundação que não era essencial, pudesse ter o topete de nomear uma pessoa contrariando a opinião do SNI? É porque o SNI não era o bicho-papão que se diz. Tanto assim que foi possível nomear um homem como o Carlos Morel, duas vezes vetado, e o Antônio Sérgio Arouca, primeiro colocado em um concurso público realizado pela Escola Nacional de Saúde Pública (ENSP) e que era do Partido Comunista. Eu não quero me fazer de herói, mas se fosse uma instituição como a Gestapo, eu não teria me atrevido. Confesso tranqüilamente: se fosse uma Gestapo, eu não faria isso.

Mas eles não explicavam o porquê do veto?

Não, era segredo. O coronel sempre me dizia: "Presidente, o SNI não se explica." Ou eu aceitava ou não. No caso do Morel e em outros casos, eu resolvi saber o porquê com o brigadeiro do DSI do Ministério da Saúde. Aparentemente ele não sabia. Eu disse: "Vou nomear." Escrevi 
"A minha política

foi de integrar as atividades que

pudessem

convergir para o

que era o

objetivo: a

realização da

pesquisa

multidisciplinar e

interligada com o

ensino, a

produção e assim

por diante". uma nota particular ao ministro: "Ministro, a biologia molecular é uma área fundamental dentro da instituição. Não conheço o Morel pessoalmente mas dizem que é um excelente pesquisador, apresentou um projeto muito bom com apoio de entidades internacionais. Ele é professor da Universidade de Brasília. Logo, já passou pelos meandros do SNI." O ministro topou. Ao brigadeiro eu disse a mesma coisa: "Este homem já é do serviço público, em uma instituição onde ele é muito mais perigoso. Não entendo como um professor em Brasilia não pode ir para Manguinhos, onde ele vai ficar restrito. Não vai ter contato para dissolver a cabeça dos jovens. Não tem nem jovem para ele subverter. Brigadeiro, me desculpe, mas isso é um negócio idiota, totalmente cretino." O caso do Arouca foi diferente. Eu realmente fiquei com raiva. Fiz um nota dura para o SNI: "Foi feito um concurso público aberto pela instituição. Se queriam fiscalizar a 'subversividade' dos candidatos deveriam ter fichado essa gente na hora da inscrição e não depois de terminado o concurso." Eu não tinha razão? O camarada passou em primeiro lugar e agora eu não posso nomear porque é subversivo? O coronel Gonçalves me apoiou, mas disse: "O senhor sabe que vai ficar mal." "Não, coronel, não vou ficar mal. Por que não fizeram antes coronel?" "Porque não recebi ordens." "Então azar. Ora bolas, que coisa mais idiota!" O negócio das viagens ao exterior era ainda mais estúpido. Meu Deus! Por que o camarada ia sair daqui para fazer subversão na França ou nos Estados Unidos? Que coisa mais doida! Se era para fugir do país podia ter ido antes, não é mesmo?

\section{Em 6usca de novos rumos para Manguinhos}

Quais as medidas substantivas que o senhor adotou para reorientar as atividades da instituição?

Eu achei que tinha uma missão a cumprir, e me vali muito da experiência de Oswaldo Cruz. O mito de Oswaldo Cruz é realmente muito forte, tem um sentido e um valor. Eu pensava que o grande segredo do instituto foi pôr em prática algo que, hoje se sabe, é a razão de ser do desenvolvimento tecnológico e econômico: a junção da pesquisa, do ensino e da aplicação em termos de produção. Tínhamos nas mãos os elementos para fazer isso na fundação. A primeira coisa que eu pensei foi: ou bem a gente desagrega tudo isso e cada um vai para o seu lugar, ou bem a gente realmente agrega e integra. A minha política foi de integrar as atividades que pudessem convergir para o que era o objetivo: a realização da pesquisa multidisciplinar e interligada com o ensino, a produção e assim por diante. Como as instituições de que dispúnhamos se prestavam a isso, foi preciso juntá-las. O Instituto Evandro Chagas não estava bem de acordo com o que queríamos, tinha outro sentido, e saiu do âmbito da fundação. O Instituto Oswaldo Cruz permaneceu como Instituto Oswaldo Cruz mesmo, porque era o cabeça da chapa. A ele foi incorporado o Instituto de Leprologia, que não tinha mais do que uma pesquisadora. 
“...cada

pesquisador

trabalha por si e

dificilmente um

diz ao outro o

que está

descobrindo.

Existe uma

anedota famosa

que se conta nos

meios

internacionais.

Dois

pesquisadores

trabalham

durante quarenta

anos em um

laboratório, um

de costas para o

outro. Vm dia,

por acaso, os

dois se

encontram e

batem um no

outro: - Quem é

você? How are

you?"
O senhor substituiu a estrutura departamental por programas de pesquisa. Qual foi o objetivo dessa mudança?

Propus ordenar a área de pesquisa, torná-la integrada e multidisciplinar. $\mathrm{O}$ viés do planejamento fez com que eu tentasse sistematizar o programa de pesquisa. Por exemplo, o controle da doença de Chagas e a esquistossomose eram grandes projetos prioritários. Dentro desse programa ou projeto de doença de Chagas, tinha os vários planos de trabalho. Para dar cunho coletivo a esses trabalhos, nós criamos a Coordenadoria de Projetos, que tinha um coordenador em torno do qual as pessoas deviam se reunir. Essas idéias não deram certo porque o ambiente não era favorável a esse trabalho coletivo. Cheguei à conclusão de que cada pesquisador trabalha por si e dificilmente um diz ao outro o que está descobrindo. Existe uma anedota famosa que se conta nos meios internacionais. Dois pesquisadores trabalham durante quarenta anos em um laboratório, um de costas para o outro. Um dia, por acaso, os dois se encontram e batem um no outro: "Quem é você? How are you?" Quer dizer, quarenta anos depois e um não sabia quem era o outro. Havia esse ambiente em Manguinhos. Isso é muito próprio dos meios científicos.

Mas essa proposta teve como base alguma experiência concreta?

Eu vi no Instituto Pasteur na França, que é um modelo e, ao mesmo tempo, um horror de individualismo, gente trabalhando assim. Eu fui a Lille, por exemplo, onde existe um núcleo do Instituto Pasteur muito importante e lá eles trabalham assim. Tinha uma reunião semanal toda falada em inglês, o diretor me disse: "O camarada vai lá para fora, nas conferências, e se não falar inglês, ele está perdido.” Nós tínhamos o modelo do Ipea que funcionava mais ou menos assim. Eu apliquei isso. Quer dizer, reúne todo mundo, vamos fazer a coordenação, discutir, botar as idéias para fora. Realmente não foi fácil, mas eu tinha a impressão de que apesar da hesitação, da resistência, no final muita gente participava dessas idéias e me apoiava.

A conversa com os pesquisadores foi muito difícil?

No início foi tremendamente difícil. Primeiro, porque a linguagem era difícil. Eu era um homem saído de um meio totalmente diferente. Aquele linguajar científico, biológico, para mim, era 'javanês'. Foi preciso aprender 'javanês'. E eu aprendi muito. Tanto assim que nas últimas reuniões do Conselho Científico, o Zeferino Vaz, da Universidade Estadual de Campinas (Unicamp), me disse: "Como é que você aprendeu tudo isso?" "A duras penas." Eu tive que ler à beça. Havia também uma grande prevenção deles em relação não somente a mim, mas ao governo, ao ministro, aos colegas, a tudo. $\mathrm{O}$ pesquisador era um homem ensimesmado lutando por uma verbinha, conseguida a duras penas, para ter material, para ter um laboratório. Fiquei precavido e vi as dificuldades para efetivar as mudanças. Dentro da instituição a falta de apoio era total. Depois eu vim a perceber que não era falta de apoio nem indiferença. Hoje eu vejo 
"Cada um tinha compromisso com seu interesse científico e com o CNNPq, mas não com a instituição". que era hesitação e preconceito. Era medo da autoridade. Quem eu era? Ninguém sabia para que eu tinha ido para lá. Eu era autoridade, e ainda pior, autoridade do governo militar, e o governo militar era o horror do mundo. Eu só tinha importância porque podia tirar alguma coisa deles.

Como o senhor se aproximou dos pesquisadores?

Era muito difícil conversar porque as pessoas não iam às reuniões. Então, eu tive que me aproximar de algumas lideranças ou supostas lideranças. Aos poucos, fui fazendo reuniões e lá eu expunha: "Bom, eu vim aqui para isso." Silêncio total. Eu provocava. "Por favor, eu quero que vocês me dêem opinião." Silêncio. Ninguém falava. Simplesmente, o que pode haver de pior, o mais trágico numa situação dessa, é esse mutismo total.

\section{Eles não tinham nenhuma proposta?}

Nem proposta nem crédito. Não havia credibilidade. Quer dizer, ninguém acreditava que eu fosse para lá com algum objetivo, que eu estivesse falando sério. Havia uma total falta de compromisso em Manguinhos: essa é a realidade. Cada um tinha compromisso com seu interesse científico e com o CNPq, mas não com a instituição. Mas não culpo os pesquisadores. Não posso ter compromisso com um instituto que não tem um programa, que não tem uma mensagem. Começou a haver um diálogo duro com o pessoal da escola, que tinha uma certa independência e um projeto político. Com essas pessoas eu tive discussões duras, mas pelo menos havia diálogo. Podiam ser de oposição ao governo: falem contra, mas falem.

Diante de tantas dificuldades, como o senhor conseguiu reorganizar a área de pesquisa?

Convidei o professor Wladimir Lobato Paraense, que estava na Universidade de Brasília, para ser vice-presidente de Pesquisa. Eu não estava entrosado no meio da pesquisa biológica e precisava de alguém que me orientasse, pois não entendo nada dessas coisas. Eu estava num verdadeiro apostolado e ficava com raiva quando o sujeito não vestia a camisa. Mas o Lobato sabia que meu objetivo era repovoar e rejuvenescer Manguinhos, ele acreditou e me deu total apoio. Ele era muito rigoroso. Por exemplo, fizemos um levantamento nos laboratórios e constatamos que havia uma quantidade enorme de estagiários. Essa situação se eternizava, porque a instituição não tinha um quadro de acesso e nem concurso. Havia jovens já com seus quarenta anos de idade que estavam lá há dez anos, coitados!

Como o Conselho Técnico Científico, criado pelo senhor, contribuiu nessa reorganização?

Como eu afirmei, a instituição não tinha muita credibilidade. Senti a necessidade de um apoio de alto nível científico. Queria que esse 


"Senti a
necessidade de
um apoio de alto
nivel científico.
Queria que esse
conselho fosse
formado por um
grupo de
cientistas e de
professores de
renome, desse
respaldo
cientifico interno
e externo ao
presidente da
Fiocruz".

conselho fosse formado por um grupo de cientistas e de professores de renome, desse respaldo científico interno e externo ao presidente da Fiocruz. Já mencionei que não havia uma participação muito intensa dos pesquisadores. Eu ficava muito aborrecido porque não havia ressonância do que eu falava. Acredito que em grande parte essa falta de colaboração se deveu ao caráter intrínseco do pesquisador. É de sua natureza voltar-se para a sua atividade. Para eles, a minha linguagem era algo novo. Os aspectos nacional, social e econômico da pesquisa não eram percebidos por eles. Ou eles ficavam no laboratório fazendo pesquisas em profundidade, sendo obrigados a ler centenas, artigos científicos para se atualizar, ou então prestavam atenção à instituição como um todo. Nesse caso, seriam administradores de ciência e não cientistas. Por isso, creio que uma instituição como aquela será bem administrada por alguém que não seja especificamente um pesquisador.

O conselho era uma forma de legitimar o seu trabalho.

Exato. O conselho seria uma prova, um testemunho, de uma certa aceitação da fundação. Isso foi uma preocupação muito grande porque muita gente, por uma razão ou outra, se recusou a ir para Manguinhos. As pessoas não acreditavam e não queriam ir para lá. Tive que, aos poucos, ir pegando a laço quem eu queria lá.

Quem o senhor chamou para fazer parte desse conselho?

Compusemos um conselho constituído pelo presidente e pelo vice-presidente de Pesquisa, Wladimir Lobato Paraense, pelo vicepresidente de Recursos Humanos, Guilardo Martins, e por cientistas de outras instituições, como, por exemplo, Academia Brasileira de Ciências, Instituto Adolfo Lutz de São Paulo, Universidade Federal do Rio de Janeiro, Instituto Evandro Chagas, Universidade de Brasília, Instituto Butantã, Unicamp, Universidade da Bahia. Além desses, convidei um pediatria do Hospital dos Servidores do Estado e um representante da iniciativa privada ligado à pequena indústria farmacêutica. Escapou-me, na época, um representante da Academia Brasileira de Medicina.

O senhor chegou a fazer reuniões com essas pessoas?

Claro, tive o prazer de ter com eles uma reunião mensal. Era um dia inteiro de discussão. Primeiro, apresentei a reorientação programática de Manguinhos, aquela idéia da atuação por objetivos, os programas e os projetos. Houve sempre uma participação muito grande. $\mathrm{O}$ conselho era consultivo e não deliberativo, embora muitos pensassem que fosse. Mas eu levei muito em conta a opinião deles, tanto assim que o projeto de restruturação foi aprovado pelo Conselho Técnico Científico e encaminhado ao ministro. 


“Tínhamos
contemplado as
doenças
parasitárias, mas
não tínhamos
quase nada em
doenças
infecciosas... o
instituto tinha
ficado
praticamente na
época de
Oswaldo Cruz e
de Carlos
Chagas. Então,
incentivamos as
áreas deficitárias,
como a virologia
e a bacterologia,
a imunologia, a
genética e a
biologia
molecular”.

"Tinhamos

contemplado as

doenças

parasitárias, mas

não tínhamos

quase nada em

doenças

infecciosas... o

instituto tinha

ficado

praticamente na

época de

Oswaldo Cruz e

de Carlos

Chagas. Então,

incentivamos as

áreas deficitárias,

como a virologia

e a bacterologia,

a imunologia, a

genética e a

molecular".
Lemos nos Relatórios de Atividades desse periodo que o senhor priorizou certos campos de pesquisa. Quais foram os critérios utilizados para chegar a essa definição?

Muita gente não sabe por que demos prioridade a duas doenças parasitárias: Chagas e esquistossomose. Elas não eram mais importantes do que as doenças infecciosas, mas eram dominantes em Manguinhos porque reuniam o maior número de laboratórios interessados: em primeiro lugar, Chagas e, em segundo, esquistossomose. Havia ainda o projeto de leishmaniose. Tínhamos contemplado as doenças parasitárias, mas não tínhamos quase nada em doenças infecciosas. Quer dizer, o instituto tinha ficado praticamente na época de Oswaldo Cruz e de Carlos Chagas. Então, incentivamos no IOC as áreas deficitárias, como a virologia e a bacterologia, de vital importância, a imunologia, a genética e a biologia molecular. A área de pesquisa foi organizada sob a ótica de projetos multidisciplinares e integrados, saindo, assim, do contexto dos projetos individualizados muito mais restritos. Foi isso que se pretendeu montar em Manguinhos.

\section{Houve parcerias nisso?}

A política de ciência e tecnologia da época era baseada em convênios. A Finep trabalhava nessa linha, tentando sair do esquema antigo do projeto individualizado. $\mathrm{O}$ sujeito devia fazer algo mais complexo, que reunisse um número maior de pesquisadores interessados para um determinado objetivo. Por exemplo, em vez de conhecer meramente o vetor de uma doença, o objetivo deveria ser o desenvolvimento de uma vacina.

O senhor teve algum contato com a Organização Mundial de Saúde (OMS) nesse momento?

Eu fiz várias visitas à OMS. Eles estavam muito interessados em nossos projetos, sobretudo na chamada medicina tropical. Tinha pensado em aproveitar a OMS também para legitimar Manguinhos no plano internacional. Pretendia abrir Manguinhos o máximo possível. Fizemos convênios também com o Instituto Adolfo Lutz, com o setor de saúde do Exército e da Marinha, e com a Organização Pan-Americana de Saúde (Opas) para a regionalização de cursos de formação de pessoal na área de saúde pública. Esse era um projeto da ENSP, o Programa de Preparação Estratégica de Pessoal em Saúde (PPREPS).

Fale sobre os seus projetos para a Escola Nacional de Saúde Pública.

A escola tinha vida própria e não havia caído naquele marasmo, naquela prostração horrível do resto da entidade. O que fiz foi ligá-la à fundação. Antes de mais nada, integrá-la fisicamente com a fundação. Fomos nós quem fizemos aquele acesso à escola dentro do campus de Manguinhos. O pessoal da escola ficava isolado e não queria muita conversa com a fundação. Eles achavam que a fundação só fazia 
prejudicá-los. Talvez tivessem razão. Se o presidente fosse do Instituto Oswaldo Cruz, ele ia puxar para o instituto. Cada um puxava para si. Por isso, por exemplo, o pessoal do Instituto Fernandes Figueira não gostou de ter passado para a fundação. Era mais interessante para eles ficarem independentes do ponto de vista orçamentário, vinculados diretamente ao ministério ou a um convênio com o Inamps. A fundação era só um transtorno.

Quais eram as atividades desenvolvidas pela ENSP naquele momento?

No meu entender, a escola funcionava muito bem, à parte os problemas políticos que causava de vez em quando. Tinha como objetivo formar médicos voltados para a saúde pública. Conheci os programas, discuti com as lideranças, inclusive as mais duras do ponto de vista político, e nossas opiniões coincidiam. Apoiei a regionalização dos cursos de formação de pessoal, realizados através de convênios com as secretarias de Saúde dos estados. O ministério estava voltado para as ações de saúde pública no interior e eu achava que a fundação tinha que ter uma atuação nacional. Essa foi, realmente, uma inovação na minha gestão.

Com que objetivo foi criado o Instituto Nacional de Controle de Qualidade em Saúde (INCQS)?

Existia no Ministério da Saúde um órgão da administração direta chamado Laboratório Central de Controle de Drogas e Medicamentos e Alimentos (LCCDMA). Funcionava no Rio de Janeiro e tinha a incumbência de fazer o controle de qualidade de medicamentos. Imagina! Controle de medicamentos numa época em que as multinacionais farmacêuticas estavam entrando no Brasil. O laboratório praticamente não existia, não tinha a menor condição de controlar. $O$ dr. Paulo de Almeida Machado, já no final da minha gestão, em 1978, começou a me falar sobre isso e insistiu muito comigo. Eu me arrepiei. Eu já estava com uma grande responsabilidade na fundação. Não quis aceitar, mas ele não concordou, e houve a transferência do laboratório para a fundação, através de um decreto do presidente da República de 30 de agosto de 1978. Essa foi a origem do INCQS.

Mas o senhor deixou a presidência da Fiocruz em março de 1979. O que conseguiu fazer em tão pouco tempo no INCQS?

Fiz um diagnóstico e verifiquei que havia 42 técnicos, dos quais creio que 38 já estavam em época de aposentadoria. Era lamentável! Não havia mais nada. Não contratei ninguém. Esses técnicos ficaram trabalhando na sede do LCCDMA, na avenida Venezuela. A única coisa que eu fiz foi o projeto físico para a instalação do INCQS em Manguinhos. 
"Depois de ajeitar as coisas em Manguinhos, comprei a briga com o Instituto Fernandes

Figueira. Eu

pensava que pesquisa tem que ser feita no Caboratório. Até que alguém me mostrou que pesquisa clínica também é pesquisa. Então eu falei:

- Provem que vocês fazem pesquisa clínica. Se vocês só fazem atendimento, vão sair da fundação".
O senhor mencionou que o pessoal do Instituto Fernandes Figueira não queria se integrar à fundação. Como foi resolvida essa situação?

Depois de ajeitar as coisas em Manguinhos, comprei a briga com o Instituto Fernandes Figueira. Eu pensava - e hoje reconheço que não tinha razão - que pesquisa tem que ser feita no laboratório. Até que alguém me mostrou que pesquisa clínica também é pesquisa. Então eu falei: "Provem que vocês fazem pesquisa clínica. Se vocês só fazem atendimento, vão sair da fundação.” A essa altura, eu já tinha conseguido decuplicar o salário médio da fundação, que passou de mil para oito mil unidades em dinheiro. Não interessava mais a eles sair da Fiocruz. Aí eu disse: "Está bom. Vocês não vão sair, mas virão para cá." Então nós elaboramos o projeto do Centro Hospitalar de Manguinhos, que seria constituído pelo Hospital Evandro Chagas para doenças parasitárias, pelo Núcleo Gaspar Vianna para doenças infecciosas, e por um núcleo materno-infantil, o Instituto Fernandes Figueira.

Mas qual foi o motivo da briga com o pessoal do Fernandes Figueira?

O Instituto Fernandes Figueira fica na avenida Rui Barbosa. Fiz um levantamento da clientela e constatei que $88 \%$ da mães moravam na zona Norte, enfrentando três conduções para chegar lá. Eu disse a eles: "Se vocês atendem uma população em sua maioria da zona Norte por que não se transferem para o campus, já que o acesso é mais direto?" $\mathrm{Ah}$, foi um deus-nos-acuda! Eu anunciei esse projeto e eles não queriam sair de lá. A briga foi essa. Eu tinha conseguido um negócio fabuloso: venderia aquela área e com o dinheiro faria o centro lá em Manguinhos. Pegou fogo! Os grandes pediatras do Rio daquela época trabalhavam lá, mas tinham seus consultórios particulares. Eles eram muito mais importantes do que a Fiocruz. Apesar de terem ficado a pão e água, sem recursos, ganhando uma ninharia, estavam lá só pelo prazer de trabalhar no Fernandes Figueira. Essa era a realidade. Fiz uma pesquisa para saber onde os médicos moravam e descobri que $98 \%$ residia na zona Sul! Eles fizeram queixa até ao Roberto Marinho. Na verdade, eles ganharam. Foi uma batalha perdida. Realmente, eu não devia ter comprado essa briga. Só entrei nessa briga por uma questão de coerência com o projeto que tínhamos para Manguinhos. O Fernandes Figueira não poderia ficar à parte. Eu achava que seria mais útil se ele ficasse no campus. Primeiro, porque participaria de um centro hospitalar, que não se realizou. Segundo, teria uma clientela muito mais próxima. Terceiro, poderia se adaptar e se enquadrar num projeto maior de medicina comunitária. Esse era o meu objetivo.

Se o Centro Hospitalar não foi construido, como ficou o Hospital Evandro Chagas?

O Hospital Evandro Chagas estava morto, acabado. Tinha três ou quatro gatos-pingados que nem estavam com doença de Chagas e foram para lá porque não tinham onde morrer. É verdade! Tanto assim 


“A história da
instituição é
fascinante, com
todo aquele
passado e com
um homem que
era um mito
nacional,
Oswaldo Cruz.
Descobrimos um
acervo
fotográfico muito
6om. Isso
impunha o
museu... toda
instituição tem
que ter um
museu... . Eu
queria que
Manguinhos fosse
visitado".

“A história da instituição é fascinante, com todo aquele passado e com um homem que

era um mito

acional, Oswaldo Cruz. acervo

fotográfico muito 6om. Isso impunfa o museu... toda que ter um museu... . Eu queria que visitado". que eu quis acabar com o hospital. Não tinha cabimento trazer um doente chagásico do fim do mundo para cá.

O que aconteceu com os núcleos do INERu?

Esses núcleos foram mantidos. Tentei ligá-los diretamente às universidades porque pensava que essa era a única maneira de fazê-los funcionar. A essa altura, as universidades brasileiras tinham tomado um grande impulso. Em 1975, a reforma universitária já tinha dado frutos. Pernambuco, Bahia e até a Paraíba tinham boas universidades. O único que ficou mais ligado a Manguinhos foi o Centro René Rachou.

Existia um museu no prédio do Castelo. Foi o senhor quem o criou?

Sim. A história da instituição é fascinante, com todo aquele passado e com um homem que era um mito nacional, Oswaldo Cruz. Descobrimos um acervo fotográfico muito bom. Isso impunha o museu. Creio que toda instituição tem que ter um museu, pelo menos se você tem coisas para mostrar. Eu queria que Manguinhos fosse visitado. Fiz um plano de visitas organizadas de escolas, ainda na minha gestão, ao que chamamos Museu Histórico Didático.

Nessa área de divulgação e informação cientifica, como o senhor lidou com a famosa biblioteca de Manguinhos?

A biblioteca foi uma área que eu não mexi muito, pois tinha uma mulher que era uma instituição, dona Emília Bustamante. Ela mantinha aquela beleza de biblioteca, apesar de todo o declínio de Manguinhos. Ela nunca me bajulou, pelo contrário. Mas tudo o que ela me pediu eu dei, inclusive a infra-estrutura contra incêndio. Era um perigo! Fizemos um projeto com o Corpo de Bombeiros. A única coisa que ela pleiteava e que eu não pude dar, mas que prometi, era a mudança da biblioteca. Fiz questão de prestigiar a biblioteca. Tanto assim que as reuniões com o presidente Geisel, nas duas visitas que ele fez à fundação, foram na biblioteca.

\section{As vacinas em destaque}

Quanto à área de produção, como se estruturaram Bio-Manguinhos e Far-Manguinhos?

Quando criaram a Fiocruz instituíram artificialmente o Instituto de Produção de Medicamentos (Ipromed) para justificar a atividade de produção feita pelos pesquisadores nos laboratórios do IOC. O Ipromed fazia uma série de vacinas: pertussis, herpes, anticolérica, antitifóidica, antitetânica, antivariólica, anti-rábica, antigripal e contra a febre amarela. $\mathrm{Na}$ realidade, ele existia apenas no nome mas não como unidade física. Quanto aos medicamentos, não tinha quase produção, vendiase muito pouco. Nós substituímos o Ipromed por Far-Manguinhos, 
"Quando criaram

a Fiocruz

instituíram o

Ipromed para

justificar a

atividade dos

pesquisadores do

IOC. O Ipromed

fazia uma série de

vacinas: pertussis,

herpes,

anticolérica,

antitifóidica,

antitetânica,

antivariólica, anti-

rábica, antigripal

e contra a febre

amarela. ...

Quanto aos

medicamentos,

não tinha quase

produção,

vendia-se muito

pouco. ...

substituímos o

Ipromed por

Far-Manguinhos e

Bio-MManguinhos". para a produção de fármacos, e Bio-Manguinhos, para a produção de imunobiológicos. Criamos essas duas áreas porque havia uma distinção nas suas atividades em termos de pessoal e de equipamento. FarManguinhos trabalharia dentro do esquema da Ceme, a Central de Medicamentos que foi organizada para enfrentar a liquidação da indústria farmacêutica nacional. Durante um período, ela fez um trabalho muito duro e me associei imediatamente a isso. Na época, eu estava imbuído da idéia de ter uma certa autonomia. Veja que coisa, autonomia farmacêutica! Imagina, lutar contra as multinacionais! A Ceme conseguiu reunir determinados laboratórios públicos, como, por exemplo, o laboratório do Exército e da Marinha. Fizemos um convênio com eles e ela forneceria os recursos e daria a linha geral, especializando cada laboratório na sua área. Era uma rede nacional de fármacos. $\mathrm{O}$ objetivo não era nem tanto produzir, mas saber $\mathrm{o}$ custo.

O senhor não tinha idéia dos custos da produção de fármacos?

Ninguém sabia, ninguém sabe até hoje. Só sabíamos que você importava fármacos a cem unidades de moeda a miligrama, quando na verdade custava um a miligrama. Agora, como provar o superfaturamento?

Já era um escândalo?

Um escândalo! A Ceme foi o único momento na história do Brasil em que o governo topou essa briga. Mas, na verdade, o que aconteceu foi que a Ceme incomodou as multinacionais de tal modo que não conseguiu sobreviver e aos poucos foram the tirando os recursos. Logo eu percebi que Far-Manguinhos tinha muito pouca coisa para dar, embora tenha feito determinados projetos. Mas dei maior importância a Bio-Manguinhos.

Por que o senhor priorizou a área de produção de vacinas?

Eu pensava, e ainda penso, que uma boa solução para a fundação era se voltar para um tipo de produção que pudesse lhe dar uma certa liberdade financeira, para não ficar mamando nas tetas do governo, como dizia o Delfim Neto. Como a pesquisa não garante essa autonomia, dei força para fazer vacina. A experiência de Oswaldo Cruz pesou. Havia toda uma história. O Castelo de Manguinhos foi feito com recursos provenientes da venda da famosa vacina da manqueira. Por que fiz isto? A área tecnológica era desprezada pelo pessoal em Manguinhos. Existiam os famosos pesquisadores classe $\mathrm{A}$ e os pesquisadores classe Z. Parecia o Admirável mundo novo do Aldous Huxley: havia os alfaalfa e os ipsilones. Por que o ipsilone é ipsilone? Por que faz vacina? Pelo amor de Deus! Fazer vacina é tão importante quanto fazer pesquisa sobre moluscos. Fazer uma boa vacina é importante e difícil. O Brasil não fabricava nada, importava quantidades fabulosas de vacina. Quando produzia, era em moldes antigos, ninguém sabia o processo mais moderno de fermentação. Eu achava importante ter uma unidade de 
"A área

tecnológica era

desprezada...

Existiam os

famosos

pesquisadores

classe $\mathcal{A} e$ os

pesquisadores

classe Z. Parecia

- Admirável

mundo novo do

Aldous Huxley:

havia os alfa-alfa $e$

os ipsilones. Por

que faz vacina?

Pelo amor de

Deus! Fazer

vacina é tão

importante

quanto fazer

pesquisa sobre

moluscos". vacinas a partir do que sabíamos fazer melhor do que os outros: a vacina da febre amarela. Ela seria o ponto de partida. Era a única que funcionava, pois havia um compromisso e o governo fornecia os recursos. Existia equipamento, produção e estoque, mas se baseava num processo produtivo antiquado, segundo pude perceber depois através de meus assessores. Chamei o José Fonseca da Cunha para fazer uma revisão e aplicar a nova tecnologia de ovo embrionado.

Naquele momento, a questão da produção de vacinas estava em evidência. Pouco antes de o senhor assumir a presidência da Fiocruz, houve uma epidemia de meningite no pais.

Fui para Manguinhos, de certo modo indiretamente, por causa da vacina da meningite. Foi quando conheci o Paulo de Almeida Machado. Se você percorre os jornais da época, vai ver que foi um episódio dramático. Uma coisa é sarampo, coqueluche, doenças com as quais todo mundo convive. Mas meningite é uma doença terrível. Aquele surto foi muito sério, provocou uma celeuma no governo, uma atitude de apreensão. $\mathrm{O}$ dr. Paulo pleiteou uma vacinação em massa. Compramos oitenta milhões de doses de vacina do Instituto Mérieux, o único produtor mundial. Eu me lembro que se gastou um absurdo, quarenta milhões de dólares! Eu ainda era o coordenador da área de saúde do Ipea e o ministro do Planejamento, Reis Veloso, jogou o assunto na minha mão. Através desse contato com o Mérieux, consegui implantar em Manguinhos, tempos depois, a chamada Unidade Piloto para a produção de vacina antimeningocócica.

\section{Como foi implantada essa Unidade Piloto?}

O país sempre importou vacina de outro tipo, mas essa era uma vacina nova, que nunca se cogitou em usar no Brasil. Para não ter que importar era preciso manter alguma produção de vacina de meningite e formar estoque, pois de vez em quando havia um surto. Aproveitamos a oportunidade para induzir o Instituto Mérieux a nos doar aquela instalação de Manguinhos. Não foi fácil porque ele queria ter o domínio da fábrica.

Mas ele transferiu a tecnologia?

Transferiu, sem dúvida nenhuma, e não pagamos nem um tostão! $\mathrm{O}$ orçamento de Manguinhos e a contabilidade estão abertas para quem quiser ver. Na verdade, a idéia era transformar essa Unidade Piloto em uma unidade de aprendizagem de novas tecnologias. Manter uma pequena produção para meningite e partir para um núcleo de transformação tecnológica e de produção de outros tipos de vacinas. Meu interesse era criar, no Brasil, um núcleo de produção de vacinas. Por que conseguimos esse apoio do Mérieux? $\mathrm{O}$ dr. Charles Mérieux não era propriamente um empresário, era um homem de pensamento idealista, um visionário. Ele queria formar um grupo capaz de enfrentar as grandes multinacionais de vacina. Era um projeto extremamente 


\section{"Fui para \\ Manguinhos ... por causa da vacina da meningite. ... foi um episódio dramático. Uma coisa é sarampo, coqueluche, doenças com as quais todo mundo convive. Mas meningite é uma doença terrível".}

ambicioso e um pouco quixotesco. Para isso, ele pensava que podia contar conosco. Ao Instituto Mérieux interessava ter na Fiocruz um núcleo com a sua tecnologia que fixasse a sua imagem na América do Sul. Ele pretendia vender vacinas humanas, como sarampo e poliomielite, da qual éramos muito dependentes do Sabin. Eu acho que o dr. Mérieux tinha muito ciúme do Sabin.

Quando o senhor começou essa negociação?

Em 1976, porque antes não era possível mostrar aos franceses que existia uma fundação. Só então foi possivel trazê-los aqui e mostrar que havia um orçamento que permitiria que aquela estrutura funcionasse. No convênio que fizemos com o Mérieux foi prevista a permanência de uma equipe francesa, composta por seis ou oito técnicos, que ficou aqui durante vários meses para instalar a unidade e formar os brasileiros. Essa vacina seria produzida com uma tecnologia nova que exigiria gente nova, porque as pessoas que estavam lá não se identificavam com esse tipo de produção. Contratamos uma equipe de técnicos brasileiros, inclusive Akira Homma, que estava fora do Brasil e que se tornou superintendente de Bio-Manguinhos.

\section{Isso implicou aumento nas despesas da Fiocruz?}

No início, essa unidade não deu tanta despesa porque o equipamento, uma parte do material e a matéria-prima eram franceses. $\mathrm{O}$ chefe de produção do Mérieux ganhava oito mil dólares por mês. Como é que eu podia pagar? Não tinha a menor condição. Conseguimos até uma verba extra, em francos franceses, com a qual foi possível contratar certos técnicos para a própria área de pesquisa, como o Hélio Gelli Pereira, um virologista brasileiro que trabalhava em Londres.

Depois de instalada essa Unidade Piloto e de ter estruturado BioManguinhos em torno dela, o senhor iniciou as negociações para implementar a produção da vacina contra o sarampo?

Para o Ministério da Saúde, a prioridade maior era a produção de vacina contra o sarampo. Propusemos então um acordo ao dr. Charles Mérieux. Ele estava interessado que adotássemos a sua vacina. Ele queria dar apoio à constituição de uma joint-venture e isso vinha totalmente ao encontro do que eu pretendia. Eu era ambicioso a esse ponto.

A mesma tecnologia aplicada na produção de vacina contra a meningite poderia ser utilizada?

Sim, usaríamos os equipamentos e o know how. Mas realmente ficou difícil. A vacina do Mérieux nunca chegou a ser produzida aqui. Nossa idéia era que o Brasil fosse auto-suficiente em vacinas, mas o lobby é muito forte. O que aconteceu comigo, como presidente da fundação, foi mais ou menos isso. Quando os entendimentos com o 
"apresentei ao

ministro um

trabalho que

continha idéias

para o futuro da

instituição, dentre

as quais constava

o projeto de

organização de

uma empresa

multinacional,

uma sociedade

anônima, da qual

Manguinhos seria

a holding".
Mérieux avançaram para a formação da joint-venture, que teria a fundação como sócia majoritária, viram que talvez o Brasil pudesse ter acesso e domínio dessa tecnologia. Aí começou a entrar areia. Saí da fundação sem resolver esse problema.

Quando houve o acordo de transferência de tecnologia para a produção de vacina contra o sarampo com o governo japonês, o senhor já não estava mais na fundação?

Não, já não estava mais. Eu saí da fundação sem ter uma idéia segura do que seria Bio-Manguinhos. Sabia apenas que era preciso criar uma estrutura forte que não poderia estar muito ligada ao serviço público. Antes de sair, apresentei ao ministro um trabalho que continha idéias para o futuro da instituição, dentre as quais constava o projeto de organização de uma empresa multinacional, uma sociedade anônima, da qual Manguinhos seria a holding. No último item desse trabalho escrevi: "Outra modificação estrutural, administrativa, a meu ver, indispensável para se consolidar a recuperação da Fiocruz, é a instituição de uma sociedade anônima, Bio-Manguinhos S.A., que sucederia, na área de produção, a atual unidade técnica do mesmo nome." $\mathrm{O}$ projeto contou com muito boa receptividade por parte do BNDES, que seria o segundo sócio da empresa, ao lado da Fiocruz. "A sociedade seria aberta à participação de empresas privadas do ramo, assegurando-se desse modo a sua gradativa privatização, sem que com isso a Fiocruz deva chegar à posição minoritária. A constituição da empresa aparece na forma mais apropriada para tornar a Fiocruz cada vez mais autônoma do ponto de vista econômico-financeiro." Para alguns da fundação essa sugestão era um absurdo, eu estava dizendo uma heresia. $\mathrm{O}$ ministro aceitou, mas não deu continuidade. Infelizmente, esse projeto não foi adiante.

Em 1979, João Figueiredo assumiu a presidência da República. Foi cogitada a sua permanência no cargo ou o senhor fez um pleito nesse sentido?

Não, havia uma mudança total de governo. Fui convidado para trabalhar na Organização de Cooperação e Desenvolvimento Econômico (OCDE), cuja sede é em Paris, para onde fui em março de 1979. Guilardo Martins já tinha sido indicado para assumir a presidência da Fiocruz.

Queremos encerrar agradecendo a sua disposição em prestar este depoimento.

Eu agradeço a vocês. No início relutei muito, tinha uma certa prevenção porque achava que durante um período eu era persona non grata na fundação. Não sei se é uma realidade, mas senti isso da parte de muitas pessoas. Então, para que voltar a um passado que não é o meu passado inteiramente? A fundação foi uma experiência humana 
impressionante, mas foi uma etapa da minha vida. No entanto, pensei que valia a pena voltar ao passado. Por isso, lamento realmente ter deixado de atender a seus convites anteriores, e ter jogado fora documentos que continham um manancial de informações. Foi uma pena.

Por que essa experiência foi tão impressionante?

Em primeiro lugar, pelo desafio de entrar num meio totalmente novo, uma experiência que não correspondia ao que eu conhecia. Eu tinha uma atração muito forte pela demografia, que tem certa proximidade com a saúde. Durante anos, trabalhei em urbanismo e estatística. Portanto, o fato de ter ido para a fundação não correspondia realmente a um interesse intelectual profundo, como o que eu tinha por outras coisas. Era um ambiente novo. Em segundo lugar, pelo horror físico que era aquilo. Em terceiro, a própria convivência humana era difícil, como mostrei a vocês. Fui para lá com muito entusiasmo, pensando que ia encontrar um meio permeável à discussão das idéias. Em quarto, a própria desvinculação do meu meio de trabalho. Fui cada vez mais absorvido por Manguinhos, e isso, de certa forma, estava me isolando. Eu estava saindo do meu meio e não entrando no outro porque este não podia me aceitar. $O$ que eu poderia fazer num instituto de pesquisas ou numa escola de saúde pública? Esses fatos mostram que para mim foi uma experiência muito dura como ser humano, como profissional, mas, ao mesmo tempo, uma experiência que eu nunca tinha tido e, portanto, muito enriquecedora. Tive que enfrentá-la. Não foi fácil.

Mas o senhor obteve resultados.

É, sem falsa modéstia, devo reconhecer que obtive. Por isso eu tinha uma certa mágoa.

O senhor nunca mais voltou lá?

A minha posição era de reserva diante disso tudo. Uma vez o Herman Schatzmayr (pesquisador da Fundação Oswaldo Cruz) me convidou para almoçar lá, mas eu me senti clandestino. Foi estranho. Quer dizer, o dia em que você se sente clandestino entrando numa casa que ajudou a reconstruir, é horrível. Por isso achei interessante essa entrevista. Foi uma experiência que me proporcionou reviver uma série de coisas que eu tinha esquecido completamente, tinha abolido da memória. Foi realmente muito interessante e quero rever Manguinhos. Um dia vou lá ver o museu.

Ficha técnica

Local da entrevista: Rio de Janeiro.

Data: junho a outubro de 1995

Duração: 12 horas

Entrevistadores: Nara Azevedo e Wanda Hamilton

Edição da entrevista: Wanda Hamilton e Nara Azevedo 